\title{
ІННОВАЦІЙНА ДІЯЛЬНІСТЬ САНАТОРНО-КУРОРТНИХ ЗАКЛАДІВ: ПРОБЛЕМИ, ВАРІАНТИ РІШЕНЬ, ОСВІТА
}

Стрікаленко Т. В., доктор медичних наук, професор, Одеська національна академія харчових технологій, м. Одеса, Украӥна

Д'яконова А. К., доктор технічних наук, професор, Одеська начіональна академія харчових технологій, м. Одеса, Україна

Коротич О. М., викладач, Одеська національна академія харчових технологій, м. Одеса, Україна

DOI: https://doi.org/10.31435/rsglobal_conf/25022021/7425

Abstract. Development of the concept "health for healthy» in sanatoria of Ukraine, and also programs of sanatorium prevention, recovery treatment and medical rehabilitation, creation and introduction of regional programs of development of resorts demand introduction of innovative methods of conducting recreational business of rest and improvement. In this article questions are considered of introduction of some innovative methods which underline relevance of a problem of continuous training of experts of the industry of hospitality, corrections of programs of teaching some subjects for future workers of hotel and restaurant business are considered.

Keywords: Innovations, resorts, sanatoria, hotel and restaurant business, programs of development of recreational business, programs of training

Вступ. Інноваційний розвиток - це тренд сьогодення, який стосується практично усіх галузей діяльності людини. Оскільки в наш час продовжується розпочате ще у 90-х роках минулого століття стирання кордонів між самостійними у попередні часи сферами діяльності курортною справою, туризмом і готельним господарством, що тепер працюють на спільному санаторно-курортному ринку, це потребує сервіс-орієнтованого системного підходу до організації його діяльності, що має враховувати унікальні особливості кожного регіону. Як зазначає О.О. Галаченко, становлення, функціонування і розвиток санаторно-курортних послуг (як категорії соціально-культурних та оздоровчих послуг) зумовлені історичними, природнокліматичними та економічними умовами регіонів, і тому оцінку інноваційної діяльності сфери санаторно-курортних послуг регіону слід визначати з позицій ефективності самого санаторнокурортного закладу, курорту, регіону та споживачів [1].

Аналіз стану i характеру інноваційної діяльності різних підприємств дозволяє систематизувати знання i практичну цінність інновацій. Дослідженням терміну та суті «інновацій» присвячено наукові роботи Й. Шумпетера [2], А.І. Пригожина [3], В.В. Горшкова, Е.А. Кретова [4], В.Г. Мединського [5], Е.Г. Яковенко, Ю.В. Яковця [6], В.В. Безуглого [7], О.В. Шикіної і Я.С. Гончаренко [8], А.О. Литовки, О.В. Шикіної [9], О.О. Галаченко [1] та ін.

Базовою класифікацією інновацій найчастіше вважають Керівництво Осло, що рекомендує розрізняти такі їх види: (1) продуктова, тобто така, що веде до використання (впровадження) товару або послуги, які є новими або значно поліпшеними за своїми властивостями чи способами використання; (2) процесна - запровадження нового або суттєво поліпшеного способу виробництва чи доставки продукту (це зміни в технології, виробничому обладнанні, програмному забезпеченні); (3) маркетингова, як застосування нового методу маркетингу, що включає значні зміни в дизайні чи упаковці продукту, його розміщенні, просуванні на ринок або в призначенні ціни i (4) організаційна, що включає впровадження нового організаційного методу в діловій практиці підприємства, в організації робочих місць або зовнішніх зв'язків [10]. Так само, як і більшість інших класифікацій інновацій та нововведень, Керівництво Осло фактично поділяє їх на 2 категорії: виробничу (продуктові та процесні інновації) і власне ринкову (маркетингові та організаційні інновації). Для більшості підприємств, задіяних у сервіс-орієнтованому санаторно-курортному ринку, сьогодні обмеження знаходиться саме на ринку, а не у виробництві, хоча у виробничому потоці завжди $є$ те, що називають ресурсом із обмеженою потужністю. Таких ресурсів може бути декілька, що визначається, як названо вище, природно-кліматичними, історичними та економічними умовами кожного регіону.

В умовах втілення концепції сталого розвитку індустрії гостинності, що пов'язується 3 обмеженням негативного впливу цієї галузі економіки на природне і соціальне середовище, 
збільшенням іiі користі для сучасного та запобіганням зменшенню можливості майбутніх поколінь задовольняти власні потреби [2], розуміння і виокремлення названих ресурсів розвитку санаторно-курортних закладів і курортів потребує постійного вивчення та аналізу досвіду «сусідів» (бенчмаркінгу) і здатності працювати на випередження. Тобто потребує фахівців з відповідними системними знаннями щодо діяльності сфери санаторно-курортного ринку як категорії соціально-культурних та оздоровчих послуг. Адже для організації роботи санаторно-курортних закладів слід формувати інноваційні, принципово нові підходи, що грунтуються на нових засобах господарювання та максимального задоволення потреб споживачів послуг у відпочинку та оздоровленні. Не менш важливою складовою такої роботи $є$ формування відповідного світогляду і знань у майбутніх фахівців галузі гостинності - тоді, коли формуються професійне мислення та навички професійної майстерності [12].

Метою нашої роботи було обгрунтування викладених положень та аналіз робіт, що виконуються за нашої участі у цьому напрямку.

Результати дослідження. Концепція Державної цільової програми розвитку туризму та курортів на період до 2022 року, що схвалена Кабінетом Міністрів України, має одним із напрямків удосконалення мережі санаторно-курортних і оздоровчих закладів. Адже Україна займає одне 3 провідних місць в Європі за рівнем забезпеченості цінними природними лікувальними ресурсами, на базі яких у минулі роки було створено 240 курортних населених пунктів. Лише 47 із них на цей час належать Україні - через окупацію АРК (Криму) та складну ситуацію з частиною Донецької та Луганської областей. В Одеській області знаходяться 22 курортні населені пункти - це майже 45\% курортного запасу держави. Станом на 2017 р. в Україні налічувалось 4256 колективних засобів розміщення, санаторно-курортних та оздоровчих закладів, кількість яких зменшилась на $30 \%$ у порівнянні 3 попередніми роками.

Україна має великий курортно-рекреаційний потенціал, однак існуюча курортна матеріально-технічна база застаріла, що негативно позначається на іiі завантаженні i функціонуванні. Статистичні дані по Одеській області за останнє десятиріччя вказують на неухильне скорочення санаторіїв та пансіонатів з лікуванням на 40\% i, навпаки, стабілізацію та тенденцію до зростання на 25\% готельної бази. Виконаний М.О. Крамаренко аналіз існуючої курортної мережі показав, що кількість лікувально-оздоровчих засобів розміщення та їх розподіл на курортах Одеської області не відповідають сучасним зростаючим вимогам комфортності і потребам у лікуванні та оздоровленні [13]. Основною проблемою, що має бути вирішена на сучасному етапі, на думку автора, $є$ проблема якості і ефективності лікувально-оздоровчого процесу на курорті.

Курортні готелі з лікувальною спеціалізацією представлені по всьому світу та користуються попитом у певної категорії людей, що орієнтовані на лікування разом з відпочинком, особливо у країнах Європи (Австрія, Німеччина, Словенія, Швейцарія тощо), Азії (Індія, Китай, Тайланд), у меншій мірі - в країнах Південної та Північної Америки (Бразілія, Канада, США) і Австралії. Як зазначає М.О. Крамаренко [14], аналіз існуючого стану функціонування курортних готелів свідчить про наступні тенденції: (1) перехід від зведення одиничних будівель до комплексної забудови, укрупнення їх місткості, що обумовлено вимогами рентабельності; (2) орієнтація на внутрішні потреби країни з урахуванням потенціалу гідромінеральних ресурсів (мінеральні води, лікувальні грязі тощо); (3) зміна та розширення номенклатури приміщень залежно від комерційної спрямованості (лікування; спа; велнес; косметологія; розваги; відпочинок для ділових людей), (4) нестандартність рішень і аттрактивність архітектурного середовища курортних готелів. За даними цього дослідження, натурні обстеження більше 40 одеських готелів довели економічну доцільність будівництва курортних готелів $4 *$ i $5 *$ i, одночасно, зростаючий попит і недостатність загальнодоступних курортних готелів $3 *$. Разом 3 цим, порівняльний аналіз архітектурнопланувальних рішень курортних готелів країн Європи, Азії, Північної і Південної Америки та України за визначеними характеристиками засвідчив наявність переваг архітектурно-планувальної організації окремих зарубіжних (щодо складності об'ємно-просторових рішень, рівня комфорту, наявності додаткових функцій) i вітчизняних проектів (за зв'язком із природним оточенням, урахуванням особливостей регіональної архітектури, розвиненої лікувальної функції).

Соціально-економічними чинниками, що визначають загальносвітові тенденції проектування курортних готелів, визначені $[13,15]$ : підвищення комфорту перебування $\mathrm{i}$, одночасно, зростання попиту на цілорічне функціонування курорту (цілорічне лікування i оздоровлення на курорті); зменшення періоду перебування на курорті; збільшення кількості осіб, що віддають перевагу відпочинку 3 сім’єю; попит на додаткові послуги на території 
курортних готелів; запити на медичну профілактику на базі санаторно-курортного лікування; стрімкий розвиток спа- та велнес-індустрії; надання переваг оздоровленню на лоні природи за межами міста. Тобто, до загальних вимог до курортних готелів відносяться, в першу чергу, комфортність, цілорічність функціонування, поліфункціональність і наближеність до природи.

Важливою складовою створення комфортних умов проживання у готелях $\epsilon$ водопостачання. На жаль, аналіз якості водопостачання поселень, підприємств, окремих будинків, як і готельно-ресторанних закладів в Україні протягом останнього десятиліття свідчить про практично щорічне погіршення показників якості води, що іiі вживають як питну та використовують для приготування їжі. Якісне водопостачання закладів сфери гостинності $є$ певною іміджевою складовою оцінки країни та, власне, готелів і ресторанів, що використовують водопровідну воду для приготування їжі і напоїв (ДСТУ 4269:2003 [16]). Це не є оптимальним та потребує не лише ретельного аналізу причин, але й напрацювання заходів, здатних унебезпечити споживачів такої води. Для покращення ситуації пропонуються різні програми та варіанти, проте в складній еколого-економічній ситуації сьогодення значно простіше формулювати завдання та програми, а ніж знаходити реальні шляхи вирішення проблем, що створені нами ж.

Перспективним шляхом вирішення задачі оптимізації водопостачання у закладах сфери гостинності $є$ використання систем додаткового очищення води 3 мережі централізованого питного водопостачання та інноваційної технології оброблення води у готельно-ресторанних закладах, аналіз впливу такої води на якість деяких продуктів харчування.

Однією з вимог ДСТУ 4269:2003 [16] є цілодобова подача до усіх приміщень готелю води, що відповідає діючим в державі вимогам до показників ії якості [17]. Це досить складне завдання, що не часто реалізовано на практиці у готелях та ресторанах, незважаючи на декларації про орієнтацію на європейські стандарти якості сервісу у цих закладах. Результати досліджень вмісту тригалогенметанів (хлороформу або інших токсичних сполук, що $є$ побічними продуктами дезінфекції води хлор-вмісними реагентами) у кубиках льоду, що використовуються в барах ресторанів на морських суднах, в барах кафе та ресторанів міста, підтверджують такий висновок [18]. Перевищення гранично допустимої концентрації (ГДК) хлороформу у таких кубиках льоду складало від 2 до 50 разів, а їх концентрація була у 30\% досліджень навіть більшою, ніж у воді, що її використовували для приготування льоду. У напоях «з льодом» також виявлені залишкові кількості цього побічного продукту хлорування води. При використанні додатково очищеної води для приготування їжі в обстежених кафе, у такій воді, як і у кубиках льоду, виготовлених 3 неї, не виявлено навіть залишкового вмісту хлороформу.

Особливість додаткового очищення води полягає у збільшенні кількості бар'єрів, здатних перешкодити надходженню до споживачів води, що містить забруднюючі речовини, у тому числі такі, що не регламентовані діючими нормативними документами, проте є небезпечними для людини і здатні змінювати не лише якість продуктів харчування, але й імідж міста та готелю. Важливість таких додаткових бар'єрів зростає при низькій санітарно-технічній надійності мереж водопостачання, збільшенні кількості аварійних ситуацій на водогонах і підвищенні вірогідності терористичних дій у системі водопостачання (як поселень, так і окремих будинків, готельноресторанних та інших громадських закладів тощо). Впровадження додаткового очищення води $\epsilon$ необхідним заходом у готельно-ресторанних закладах для поліпшення якості води, що використовується як для господарських потреб (котельні, пральний та гладильний сервіс, посудомийні машини), так і для цілодобового постачання в номери, на кухню та в бар [19].

Принципова схема системи, що використовується для додаткового очищення води, має передбачати декілька шляхів використання очищеної води. Так, вода, отримана після видалення механічних домішок, солей твердості, сполук Феруму та Мангану, органічних речовин, може подаватись до посудомийних машин, котельної, пральні та гладильної. Механічного та сорбційного очищення потребує вода 3 системи централізованого водопостачання, що надходить в номери готелю, на кухню, в бар. Проведений аналіз використання додаткового очищення води в готелях міста засвідчив, що протягом року значення окремих показників якості води змінювались у воді 3 мережі централізованого питного водопостачання і були практично незмінними (на рівні чутливості методу досліджень) у додатково очищеній воді. Особливої уваги заслуговує мінімізація

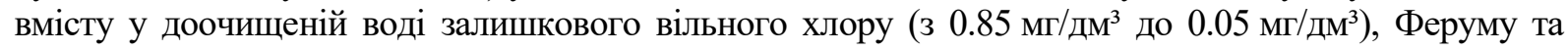
хлороформу, негативний вплив яких на якість напоїв добре відомий [20].

Задача боротьби 3 мікроорганізмами, що викликають швидку порчу продукції, виготовленої в ресторанах, інших закладах громадського харчування без використання теплової 
обробки кінцевої продукції, також $є$ актуальною, а тому досвід застосування в них інноваційної технології знезараження води безхлорним реагентом комплексної дії «Акватон-10» (діюча речовина - ПГМГ-гх), видається досить перспективним [21-23]. Так, порівняльні дослідження впливу знезаражуючих реагентів - хлору та «Акватону-10» (контроль - вода 3 системи централізованого питного водопостачання міста) - на фізико-хімічні, органолептичні та мікробіологічні показники якості зразків нектару із айви засвідчили, що найбільшу біологічну активність має нектар із айви, приготований з використанням води, знезараженої реагентом «Акватон-10» (203 у.о. - при 90.6 у.о. в нектарі, приготованому з використанням водопровідної води, та 79.9 у.о. при використанні води, додатково знезараженої хлором). Суттєві відмінності мав і вміст вітаміну С у нектарах, приготованих з використанням досліджуваних вод: 1.5 мг/100 г нектару, приготованому 3 використанням водопровідної води, і 3.2 мг/100г нектару, при виробництві якого використовували воду, знезаражену реагентом «Акватон-10». Показники епідемічної безпечності нектарів, виготовлених 3 використанням досліджуваних реагентів, відповідали вимогам для нектарів, тоді як в контролі КМАФАМ перевищувала 400 КУО/см³ .

Результати досліджень технології приготування напою «Липовий» (на основі зеленого чаю та липи) в закладах громадського харчування (на артезіанській воді, що була оброблена хлорвмісним реагентом або реагентом «Акватон-10») представлені в [24]. Отримані дані засвідчили, що показники якості артезіанської води (твердість, сухий залишок, вміст сполук Феруму та перманганатна окиснюваність) до та після ії знезараження хлором чи безхлорним реагентом комплексної дії («Акватон-10»), практично не відрізнялись та відповідали вимогам ДСанПіН 2.2.4171-10; вміст залишкових кількостей дезінфектантів не перевищував їх ГДК . Певні відмінності констатовані щодо органолептичних показників якості напою (чаю) «Липовий»: оцінка зовнішнього вигляду отриманих чаїв була практично однаковою, а за кольоровістю найвищі бали (5) отримали напої, приготовлені на артезіанській воді та тій же воді, знезараженій реагентом «Акватон-10». Колір напою, виготовленого з використанням знезаражуючого хлор-вмісного реагенту, отримав оцінку 3.7 балів. Найкращі смакові якості експерти також відзначили у напоїв, виготовлених на артезіанській воді та тій же воді, знезараженій реагентом "Акватон-10». При цьому всі експерти звернули увагу на те, що найбільшу «терпкість» мав напій, виготовлений на знезараженій реагентом «Акватон-10» артезіанській воді. Смак напою «Липовий», який готували на артезіанській воді з використанням знезаражуючого хлор-вмісного реагенту, експертами відзначено як «дуже кислий, наче без цукру» та «химерний» (хоча за даними хімічного аналізу кислотність та вміст цукру в усіх досліджених зразках напою «Липовий» практично не відрізнялись). Вміст вітаміну С у напоях, виготовлених на артезіанській воді та тій же воді, обробленій реагентом «Акватон-10», був однаковим, тоді як в напої «Липовий», приготованому на знезараженій хлором артезіанській воді, вміст вітаміну С був нижчим на $25 \%$. Ще більш суттєвою була різниця у вмісті у приготованих напоях поліфенольних речовин: в напої «Липовий», приготованому на знезараженій хлором артезіанській воді, їх кількість була нижче чутливості методу визначення, а максимальний вміст поліфенольних речовин (1272 мг/л) визначено у напої, що був приготований на артезіанській воді [24]). На думку авторів, використання реагенту «Акватон-10» для оброблення води для приготування такого напою може сприяти підвищенню ефективності цільового призначення свіжоприготованих функціональних напоїв у закладах громадського харчування, а ця інноваційна технологія є екологічно безпечною та економічно вигідною.

Таким чином, використання такої інноваційної технології як додаткове очищення води 3 мережі централізованого питного водопостачання в готелях та ресторанах, закладах громадського харчування, як і використання технології оброблення води реагентом комплексної дії «Акватон-10», здатні позитивно впливати на якість послуг, що їх надають сучасні готелі та санаторно-курортні комплекси, дозволяють зменшити витрати на ремонт комунікацій та підвищити імідж закладу. В цілому, використання інноваційних методів оброблення води та обладнання для додаткового очищення води дозволяє готувати безпечні та корисні харчові продукти, функціональні напої, переваги яких очевидні, та мають слугувати підвищенню конкурентоздатності продукції ресторанів, закладів громадського харчування тощо. Потреба в позитивних емоціях і непроста ситуація в країні спроможні справді народжувати новий споживчий досвід, а виховання культури споживання у закладах ресторанного господарства може стати вирішальним конкурентним заходом не лише задля поліпшення якості життя, але й функціонування цих закладів, зрештою - вагомою складовою політики продовольчої безпеки населення країни [25]. 
Стратегічні напрямки розвитку готельно-ресторанного бізнесу потребують фахівців, що $\epsilon$ висококваліфікованими та обізнаними із сучасними інноваційними технологіями. До таких, безумовно, належать і технології оброблення води. Доцільним вважаємо навести такий приклад: саме Свропейська асоціація спеціалістів кофейних закладів («з кофе» - SCAE) напрацювала єдиний в світі (на цей час) стандарт води для приготування кофе, що впроваджений в ресторанах Європи, США і став візитівкою престижних кафе в Україні [27].

Про важливість обізнаності із критеріями якості та безпечності різних вод, водним режимом протягом дня, побічними проявами недостатнього вживання води та особливостями різних фасованих вод свідчить і такий приклад: екскурсії до бутіка Анжело Лауріа, що оформлений як розкішний ювелірний магазин та став першим в Італії та в США «водним магазином», викликають чималий інтерес у туристів. Адже, як стверджує власник цих незвичайних магазинів, А. Лауріа, «ми хотіли показати значення води та створити достойне ії оформлення. Щоб ті, хто сюди заходить, одразу розуміли: вода - це не така проста річ, як вони, можливо, думали, і не можна iї недооцінювати. Ми допоможемо підібрати воду до м'яса чи до риби, підкажемо, якою водою завершувати трапезу, а яку використовувати як аперитив... Ви відчуєте чітку кислотність у роті, у вас розіграється апетит, у вас почне виділятись шлунковий сік, що для аперитиву є головною задачею...». I в престижних ресторанах світу, разом з картою вин, вже подають карти мінеральних і столових вод, $є$ вони і в деяких готелях України. Знання цих особливостей сприйняття та вживання води не може не сприяти підвищенню авторитету готелю і ресторану [26].

Не менш важливою задачею $є$ підвищення обізнаності працівників закладів готельного і ресторанного господарства 3 цього питання. Адже у ЗВО, що готують фахівців для харчової галузі, перші кафедри технології водопостачання були відкриті лише у 2011 році, хоча саме ця галузь особливо потребує якісну воду, яка значною мірою визначає якість приготованих страв та здоров'я людей. Міжнародний проект «Water Harmony», у виконанні якого були задіяні декілька ЗВО України, завершився розробкою, у тому числі, учбових модулів по окремим питанням обробки води в цілому, тобто для потреб централізованого питного водопостачання. Нами запроваджено викладання магістрам, що навчаються за фахом «готельно-ресторанна справа», вибіркової дисципліни «Технологія питної води і водопідготовки для закладів готельного і ресторанного господарства» (з метою засвоєння студентами теоретичних та практичних положень курсу) та розроблені Методичні вказівки до виконання лабораторних робіт 3 цього курсу, спрямовані на здобуття навичок практичного використання фізикохімічних методів дослідження води, оцінки інноваційних технологій, що вже використовують найбільш успішні заклади ресторанного господарства [26].

Як викладено у вступі, стратегію розвитку підприємств, у тому числі - санаторнокурортних закладів, найчастіше розуміють як складну управлінську стратегію, що націлена на зміну поглядів, відносин, оцінок і структур підприємства для того, щоб воно могло краще пристосуватись до нових технологій, ринків, проблем, а також до швидкості появи таких змін для забезпечення життєздатності підприємства $[1,5,7$ та ін.]. Багатьом дослідникам цієї проблеми притаманна думка, що хаотичний розвиток курортного господарства України $є$ наслідком недостатнього законодавчого i нормативно-правового забезпечення санаторно-курортної діяльності, відсутності механізму функціонування санаторно-курортних закладів в умовах ринкової економіки, незабезпечення комплексного розвитку курортних територій, зношеності основних фондів, відсутності інвестицій, низького рівня менеджменту тощо $[8,15,28-30]$. Адже така кількість проблем, обумовлених, переважно, зовнішніми чинниками, ставить можливість роботи і наявність стратегії розвитку для окремих санаторно-курортних закладів начебто неможливою. Безумовно, для вирішення проблем стратегії розвитку санаторно-курортних закладів в країні соціально-економічна політика та ситуація мають неабияке значення. Однак, в існуючих і сьогодні умовах чимала низка санаторно-курортних закладів ефективно функціонує і розвивається. I це $\epsilon$ підтвердженням того, що вплив знань на економічний розвиток як окремих установ, так і країн, постійно зростає і навіть перевищує вагомість засобів виробництва та наявних природних ресурсів. За оцінками Всесвітнього банку розвитку фізичний капітал в сучасній економіці формує $16 \%$ загального обсягу багатства кожної країни, природний - 20\%, а людський капітал - $64 \%$. Тобто, приріст створюваних цінностей відбувається за рахунок підвищення продуктивності та застосування знань на практиці, використання інноваційних технологій тощо [31].

Аналіз теорій управління дозволяє зауважити, що більшість використовуваних технологій управління націлені, в першу чергу, на одночасне поліпшення всіх процесів [32]. Тобто, 
результативність всієї системи має бути максимальною за умови роботи всіх процесів в оптимальному режимі. Такий підхід залишає поза увагою фактор взаємовпливу i взаємозалежності процесів усередині системи. Автор теорії обмежень систем (ТОС) Еллі Голдратт виходить 3 твердження, що організація - це, насамперед, система, а не просто набір процесів чи елементів. I всі складові системи пов'язані між собою причинно-наслідковими зв'язками: від того, наскільки кваліфіковано в системі збудовано взаємодію елементів, залежить іï майбутнє. Ніяке покращення існуючих процесів/елементів не приведе до помітного поліпшення, якщо зусилля не будуть спрямовані на зміцнення найслабшого елемента. Тобто, серед безлічі елементів чи процесів системи, які можуть бути оптимізовані, є лише декілька, що повинні бути покращені (оптимізовані) для реальної оптимізації роботи всієї системи $[32,33]$. А тому слід, в першу чергу, визначити обмеження системи, далі - знайти шляхи його максимального використання та підпорядкувати прийнятому рішенню всі інші елементи системи.

Суттєвим обмеженням системи надання послуг санаторно-курортного оздоровлення є різне сприйняття цінності цього продукту клієнтом (відпочиваючим) та його виробником (санаторнокурортним закладом). Якщо саме це є ключовим обмеженням (безумовно, важливий економічний чинник ефективної діяльності санаторно-курортного закладу), то пошуки шляхів збільшення сприйняття клієнтом цінності послуг санаторно-курортного оздоровлення і є пошуками реального покращення роботи закладу. Тобто, чим більшу кількість проблем клієнта/відпочиваючого вирішує послуга, що іiі надає санаторно-курортний заклад, тим більшою буде сприйняття цінності послуги, тим більше вигоди отримає клієнт, а тому питання щодо невідповідності послуги та ії ціни навіть не виникне. Програми санаторно-курортного оздоровлення, відновлювального лікування та медичної реабілітації, що розроблюються і впроваджені низкою курортів, є гарним інноваційним продуктом якщо вони достатньо обгрунтовані, ефективні, гнучкі та корисні, цілісні і зрозумілі як менеджеру (туроператору/турагенту), так і потенційному споживачу такої послуги. Важливо зазначити, що такі програми, створені з урахуванням особливостей курорту, можливостей залучення культурних, історичних та пізнавальних заходів, місцевого колориту тощо, практично неможливо відтворити в іншому місці, а тому вони $\epsilon$, безумовно, унікальними, що також додає певну ціну до їх цінності [34].

Ознайомлення студентів, що вивчають «Курортну справу», «Лікувально-оздоровчий туризм», «Рекреаційний бізнес відпочинку і оздоровлення» з основними положеннями ТОС сприяє поглибленому розумінню запитів потенційних споживачів послуг курорту (тобто їх вимог до очікуваних цінностей санаторно-курортного оздоровлення) та проблем стратегії розвитку індустрії лікувально-оздоровчого туризму, а тому видається важливим для їх подальшої успішної практичної діяльності. Апробація розробки програм для профілактики і лікування «синдрому менеджера», синдрому хронічної втоми, а також оздоровлення працівників хімічної промисловості тощо в санаторіях різних регіонів нашої країни, що ії виконують студенти на практичних заняттях 3 цих навчальних предметів, сприяє не лише засвоєнню ними конкретних знань щодо певних запитів потенційних споживачів послуг курорту. Увага до проблем організації курортної справи в регіонах, до розширення використання місцевих санаторіїв потребують поглиблення знань природних ресурсів, ступеню екологічної сприятливості, інфраструктурної забезпеченості території та, зрештою, іншого рівня розуміння перспектив курортного оздоровлення і лікувально-оздоровчого туризму. Адже індивідуальний підхід сьогодні стає стандартом - у споживачів формується нове розуміння того, якою має бути хороша, «саме для мене», пропозиція тих чи інших послуг. Важливість такого детального «оформлення» програм перебування у санаторії (на курорті) обумовлена рядом чинників, серед яких досить вагомим є формування поваги до санаторію (курорту), що так дбайливо ставиться навіть до потенційних споживачів його послуг. Крім того, сьогодні більше, ніж у попередні роки, переважає довіра до брендів та установ, що стоять за ними, як таких, які можуть максимально задовольнити потреби та вимоги відпочиваючих і туристів.

Важливими проблемами сьогодення $\epsilon$ нестабільність та непередбачуваність суспільноекономічних подій у суспільстві, «ковідна пандемія», що негативно впливають на стан психічного здоров'я населення в цілому, а можливості пристосування до таких умов життя та праці рано чи пізно вичерпуються, що сприяє виникненню післятравматичних стресових розладів (ПТСР). Сприйняття життєвих умов як катастрофи (життєвий простір, непридатний для життя) може виступати кульмінаційною точкою кризи свідомості, як зауважують автори [35], яка набагато гірша за реальну небезпеку. Розвиток поля негативних емоцій, що поглиблюється зовнішніми чинниками (надзвичайні ситуації антропогенного, техногенного чи природного характеру), притаманне і працівникам індустрії гостинності, які, до того ж, 
постійно стикаються 3 такими ж «полями» у своїх відвідувачів. Саме тому, трансформація суспільства так званої техногенної цивілізації потребує зміни в парадигмі рекреаційних потреб населення і трансформації рекреаційної системи в цілому.

Актуальність та доцільність наукового пошуку в даному напрямі зумовлені соціальним запитом на формування і культивування здорового способу життя населення та, значною мірою, профілактику розвитку ПТСР і забезпечення фізичного, психічного та духовного здоров'я. Про необхідність залучення до реабілітації людей з ПТСР можливостей курортології як наукового напрямку, акцентованого на оздоровленні та профілактиці ускладнень хронічних захворювань/станів, писали ще у 1978 р (США) - аналізуючи ефективність лікування ветеранів 3 «post-Vietnam syndrome» [36]. Останнім часом проблема реабілітації людей з ПТСР набула особливої актуальності і в Україні, а тому вивчення і використання світового досвіду - 3 урахуванням можливостей нашого санаторно-курортного комплексу - стало пріоритетним і для курортної галузі нашої країни. Адже необхідність довготривалої медико-психологічної реабілітації при ПТСР досить часто супроводжується проявами інтоксикації ліками, фармакологічною та психологічною залежністю. I тому зрозуміла зацікавленість у науково обгрунтованому використанні для корекції порушень фізичного та психічного здоров'я при ПТСР курортних природних і преформованих лікувальних чинників, різних методів лікування «без ліків» тощо [36, 37, 38]. Організація і контроль за раціональним харчуванням, дотриманням режиму дня і можливість об'єктивного контролю ефективності застосованого лікування - ці переваги санаторно-курортного етапу реабілітації при ПТСР незаперечні. Їх ефективність демонструє позитивний досвід країн США і Європи: з урахуванням етапу курортної реабілітації майже $30 \%$ хворих з ПТСР одужує, у $40 \%$ залишаються незначні порушення, у 20\% - помірні, лише в $10 \%$ випадків стан хворих не змінюється $[35,36]$.

Аналіз сучасної професійної підготовки фахівців індустрії гостинності підтверджує важливість вивчення механізмів розвитку і профілактики ПТСР для майбутніх працівників галузі та їх щоденних потенціальних клієнтів. Наш певний досвід, отриманого при включенні до програми навчального предмету «Курортна справа» окремого модулю «Курортно-рекреаційне оздоровлення при ПТСР», показав, що виконуючи практичні завдання з проектування таких програм реабілітації на окремих курортах в різних регіонах України, студенти мають змогу не лише поглиблювати свої знання, але й глибше усвідомлювати комплексну їх корисність, невід'ємною частиною якої $\epsilon$ їх робота у галузі готельно-ресторанного бізнесу [39].

Висновки. Виконано аналіз деяких напрямків інноваційної діяльності санаторно-курортних закладів, програм санаторно-курортної профілактики, відновлювального лікування та медичної реабілітації, створення і перспектив впровадження регіональних програм розвитку курортів. Розглянуто можливості впровадження деяких інноваційних методів ведення рекреаційного бізнесу відпочинку і оздоровлення. Це свідчить про актуальність і питання щодо важливості постійного навчання фахівців індустрії гостинності, корегування програм викладання певних навчальних предметів для майбутніх спеціалістів готельно-ресторанного сервісу.

\section{REFERENCES}

1. Galachenko O. (2019) Regionalna politika rozvitku sferi sanatorno-kurortnikh poslug Dis. D. e. n. Lviv. 479 p. [in Ukrainian].

2. Shumpeter I. (1982) Teoriia ekonomicheskogo razvitiia. Per. s nem. V. S. Avtonomova, M. S. Liubskogo, A. Iu. Chepurenko. M: Progress. 455 p. [in Russian].

3. Prigozhin A. (1989) Novovvedeniia stimuly i prepiatstviia sotsialnye problemy innovatiki. M: Politizdat. 271 p. [in Russian].

4. Gorshkov V., Kretova E. (1996) Innovatsionnye riski. SPb. 103 p. [in Russian].

5. Medinskii V. (2002) Innovatsionnyi menedzhment. M: Infra-M. 295 p. [in Russian].

6. Iakovets Iu. (2004) Epokhalnye innovatsii XXI veka. Mezhdunar in-t P. Sorokina-N. Kondrateva. M: Ekonomika. 444 p. [in Russian].

7. Bezuglii V. (2016) Geoprostorov osoblivost sanatorno-kurortnogo kompleksu Ukraini. Visnik Dnipropetrovskogo universitetu. Seriia geology. ia geografiia. 24 (2) P 3-10. [in Ukrainian].

8. Shiki a O., Goncharenko I. (2018) Dinamika rozvitku gotelnogo biznesu Odeskoi oblasti. Visnik sotsialnoekonomichnikh doslidzhen. 4 (68). P. 220-232. [in Ukrainian].

9. Litovka A., Shikina O. (2016) Klasifikatsiia innovats ino diialnosti turistichnogo pidpriemstva. Globalni ta natsionalni problemi ekonomiki. Mikolaivskii natsionalnii universitet im. V. Sukhomlinskogo. Vipusk 12. P. 416-420. [in Ukrainian].

10. Oslo Manual Guidelines for Collecting and Interpreting Innovation Data. 3rd Edition OECD [Rukovodstvo Oslo. Rekomendatsii po sboru i analizu dannykh po innovatsiiam. Trete izdanie. Sovmestnaia publikatsiia OESR i Evrostat]. [in Russian]. 
11. Travel and Hospitality Industry Outlook (2018). URL: https://www2 deloitte.com/us/en/pages/ consumerbusiness/articles/travel-hospitalityindustry-outlook html. [in English]

12. Andrianova I. (2009) Razvitie professionalnykh interesov studentov turistskogo VUZa v sfere gostepriimstva. Avtoref. Diss. K. ped. N. M: RMAT. 24 p. [in Russian]

13. Kramarenko M. (2018) Naukovi zasadi arkhitekturno-planuvalnoi organizats kurortnikh goteliv. Avtoref. Dis. K. arkhitekturi. K. 28 p.[in Ukrainian].

14. Kramarenko M. (2013) Sravnitelnyi analiz razmeshcheniia kurortnykh gostinits v Ukraine i za rubezhem. Visnik Odeskoi derzhavnoi akademii budivnitstva ta arkhitekturi. Odesa. Vip. 50. Chastina 1. P.164-168. [in Russian]

15. Kramarenko M. (2017) Suchasnii stan i perspektivi rozvitku sanatorno-kurortnikh ta ozdorovchikh ustanov Odeskoi oblasti. III mizhnar naukovo-prakt konf "Arkhitektura istorichnogo Kiiva. Kontekst I vtruchannia”. KNUBA. Kiyv. P. 61-62. [in Ukrainian].

16. Poslugi turistichni. Klasifikats ia goteliv. Derzhavnii standart Ukraini. DSTU 4269-2003. (2003) K: Derzhstandart Ukraini. Normativnii dokument Derzhstandartu Ukraini. [in Ukrainian].

17. Gigienichni vimogi do iakosti vodi priznachenoi dlia spozhivanniu liudinoiu. Derzhavni sanitarni pravila I normi DSanPiN 22 4-171-10. (2010) K: MOZ Ukraini. Normativnii dokument MOZ Ukraini. [in Ukrainian].

18. Strikalenko T., Voitenko A. (2012) Trigalogenmetany v kubikakh lda dlia napitkov "Voda v kharchovii promislovosti": Zb tez dop III mizhnar naukovo-prakt konf. Odesa: ONAHT. P. 177. [in Ukrainian].

19. Strikalenko T. (2015) Voda dlia gotelno-restorannikh zakladiv: analiz deiakikh shliakhiv optimizats vodopostachannia. Vodopostachannia ta vodovidvedennia. Naukovo-virobnichii zhurnal. 3. P. 31-36. [in Ukrainian].

20. Kovalenko O., Vetrov D. (2012) Tekhnologiia vodopidgotovki dlia virobnitstva chainikh napoiv: tekhnologichni aspekti ta pidkhodi do rozrobki. "Voda v kharchovii promislovosti". Zb tez dop III mizhnar naukovo-prakt konf. Odesa: ONAHT. P. 9 -10. [in Ukrainian].

21. Skubii N. (2014) Innovatsionnaia tekhnologiia obrabotki vody dlia gostinits i restoranov. "Ozdorovchi kharchovi produkti ta dietichni dobavki: tekhnologii, iakist ta bezpeka". Zb mater mizhnar naukovo-prakt konf. K: NUHT. P 130-131. [in Ukrainian].

22. Abramchuk V., Egorova A., Paulina Ia. (2013) Innovatsionnaia metodika obrabotki vody dlia prigotovleniia nektarov. "Voda v kharchovii promislovosti" Zb tez dopov IV mizhnar naukovo-prakt konf. Odesa: ONAHT. P. 36. [in Ukrainian].

23. Shendrik V. (2013) Innovatsionnaia tekhnologiia podgotovki vody i tary dlia proizvodstva nektarov iz aivy. $\mathrm{Zb}$ nauk. prats molodikh uchenikh, aspirantiv ta studentiv. T. 1. ONAHT. P 103-104. [in Ukrainian].

24. Vetrov D., Liapina O., Beregova O., Nizhnik Y. (2013) Doslidzhennia vplivu reagentiv dlia znezarazhennia vodi na pokazniki iakosti napoiu chaiu Lipovii. Naukovo-prakt konf "Voda ta dovkillia" v ramkakh XI mizhnar vodnogo forumu "AQUA UKRAINE-2013". K.: MVTS. [in Ukrainian].

25. Egorov B. (2012) Problemi ta zavdannia akademii shchodo tsilei zabezpechennia iakisnoiu vodoiu ta bezpechnim prodovolstvom zhiteliv regionu i kraini. "Voda v kharchovii promislovosti". Zb tez dop III mizhnar naukovo-prakt konf. Odesa ONAHT. P. 5. [in Ukrainian].

26. Liapina O., Strikalenko T. (2016) Perspektivi vivchennia problemi vodi maibutnimi fakhivtsiami gotelnorestorannoi spravi. "Turistichnii ta gotelno-restorannii biznes v Ukraini: problemi rozvitku ta reguliuvannia”. Mater. VII mizhnar naukovo-prakt konf. Cherkasi. CHDTU. P. 49-51. [in Ukrainian].

27. Odnorog T (2016) Idealnaia voda dlia kofe. Voda I vodoochisni tekhnologii. 1 (79)-2 (80). P. 60-62. [in Ukrainian].

28. Lebedeva V. (2011) Strategiia rozvitku pidpriemstv sanatorno-kurortnogo kompleksu. Avtoref. Dis. K. e. n. Odesa. 24 p. [in Ukrainian].

29. Gaman P. (2007) Menedzhment iak teoriia i praktika dlia kerivnika sanatorno-kurortnogo zakladu. Ekonomika ta derzhava. 9. P. 56-59. [in Ukrainian].

30. Gumeniuk V. (2017) Derzhavne reguliuvannia rinku kurortno-rekreatsiinikh poslug. Avtoref. Dis. D. e. n. K. 42 p. [in Ukrainian].

31. Strikalenko T. (2016) TOS dlia strategii rozvitku sanatorno-kurortnikh zakladiv ta likuvalno-ozdorovchogo turizmu. "Turistichnii ta gotelno-restorannii biznes v Ukraini: problemi rozvitku ta reguliuvannia". Mat. VII mizhnar naukovo-prakt. Konf. Cherkasi: CHDTU. P 14-17. [in Ukrainian].

32. Goldratt E. (2013) TSel-2. Delo ne v vezenii. M: Mann Ivanov i Ferber. 280 p. [in Russian].

33. Kouen O., Fedurko E. (2012) Osnovy teorii ogranichenii. Tallinn: TOC Strategic Solutions. 332p. [in Russian].

34. Strikalenko T. (2015) Suchasni tendentsii ta perspektivi rozvitku likuvalno-ozdorovchogo turizmu v Ukraini. "Turistichnii ta gotelno-restorannii biznes v Ukraini: problemi rozvitku ta reguliuvannia". Mat. VI mizhnar naukovo-prakt konf. CHerkasi: CHDTU. P.16-19 [in Ukrainian].

35. Innovatsiini pidkhodi do organizatsii mediko-psikhologichnoi dopomogi pisliatravmatichnogo stresovogo rozladu. Metodichn rekomendats. Pogodzheni MOZ Ukraini. (2014) K. 32 p. [in Ukrainian].

36. Meditsinskaia reabilitatsiia. Pod red V. Bogoliubova. Izd 3-e, ispr i dop. (2010) M: BINOM. 416p. [in Russian].

37. Zilov V., Minenko I. (2006) Nelekarstvennaia reabilitatsiia posttravmaticheskikh stressovykh rasstroistv razlichnogo proiskhozhdeniia. Vestnik mezhdunarodnoi akademii nauk. 2. P. 31-34. [in Russian].

38. Vedmid N. (2013) Sanatorno-kurortnii kompleks: servisne upravlinnia. Monografiia. K. 536 p. [in Ukrainian].

39. Strikalenko T. (2020) Pisliatravmatichni stresovi rozladi u programi navchalnogo predmetu "Kurortna sprava". "Turistichnii ta gotelno-restorannii biznes v Ukraini: problemi rozvitku ta reguliuvannia". Mat. XI mizhnar naukovo-prakt konf. Cherkasi. CHDTU. 1. P. 104-106. [in Ukrainian]. 